\title{
Partisipasi Masyarakat Terhadap Pelestarian Hutan Cagar Alam Di Kampung Saporkren Dist.rik Waigeo Selatan Kabupaten Raja Ampat
}

\author{
Irnawati Irnawati \\ Fakultas Pertanian Universitas Muhammadiyah Sorong \\ irnawatif@gmail.com
}

\begin{abstract}
Abstrak
Kawasan cagar alam memiliki potensi sumberdaya alam dan jasa lingkungan yang tinggi dan dapat dijadikan sebagai modal dasar pelaksanaa pembangunan Indonesia di masa yang akan datang. evaluasi kondisi komunitas hutan cagar alam di kampung Sapokren sangat berguna dalam mamantau proses regenerasi terhadap pelestarian Hutan Cagar Alam di Waigo Barat. Metode yang di pakai dalam penelitian ini adalah metode deskriptif dengan teknik observasi dan wawancara. Partisipasi masyarakat dalam pelestarian hutan cagar alam penelitian ini terdiri atas kemauan, kemampuan dan kesempatan yang dimiliki masyarakat untuk ikut serta dalam kegiatan partisipasi, Perilaku masyarakat tentang upaya pelestarian dapat dilihat dari motivasi responden mengikuti kegiatan penyuluhan yang dilakukan oleh pemerintah setempat yang mencapai 55\% dalam tingkat sukarela motivasi masyarakat yang ikut ambil bagian dalam menjaga dan melestarikan hutan cagar alam di Kampung Saporkren Distrik Waigeo Selatan.
\end{abstract}

Kata Kunci : Partisipasi Pelestarian Hutan Cagar Alam

\section{PENDAHULUAN}

Hutan cagar alam memiliki berbagai jenis dan keanekaragaman pohon pada hutan cagar alam perlu dilakukan pengamatan terhadap tegakan pohon untuk jangka waktu tertentu. Mengingat ada banyak faktor yang dapat menyebabkan perubahan struktur dan komposisi komunitas tumbuhan pada hutan cagar alam, maka dalam periode waktu tertentu komunitas Hutan Cagar Alam di Waigeo Barat perlu dievaluasi agar faktor-faktor yang dapat menyebabkan menurunnya kelimpahan dan keanekaragaman hutan cagar alam. Selain itu, evaluasi terhadap pelestarian hutan cagar alam sangat berguna dalam memantau proses regenerasi tegakan hutan cagar alam.

Kepedulian terhadap lingkungan hidup umumnya dan hutan pada khususnya tidak hanya berada dipundak pemerintah. Bagaimanapun usaha yang dilakukan oleh pemerintah dalam mengelola dan menata hutan, akan tetapi tidak mendapat dukungan berupa peran serta warga masyarakat umumnya dan khususnya masyarakat yang bermukim di sekitar hutan cagar alam kampung Saporkren, maka usaha yang dilakukan itu mustahil akan berhasil dengan baik. 
Partisipasi masyarakat terdapat pelestarian hutan cagar alam di Waigeo Selatan Kabupaten Raja Ampat juga memberikan jasa lingkungan yang besar karena keindahan alam yang di milikinya yang dapat menggerakan industry pariwisata bahari. Dilain pihak pemanfaatan potensi hutan cagar alam belum optimal akibat perhatian dan kebijakan Pemerintah selama ini yang lebih berorientasi ke Laut Raja Ampat.

Kegiatan pengelolaan terhadap pelestarian hutan cagar alam berbagai ancaman baik dari aspek ekologi yaitu terjadinya penurunan kualitas lingkungan, seperti pencemaran, perusakan ekosistem dan perburuan liar yang berlebihan maupun dari aspek sosial yaitu rendahnya aksebilitas dan kurangnya parisipasi masyarakat terhadap pelestarian hutan cagar alam. Oleh karena itu, di dalam mengantisipasi perubahan-perubahan dan acaman-ancaman tersebut, pengelolaan terhadap pelestarian hutan cagar alam harus dilakukan secara komprehensif dan terpadu. Mengingat ada banyak faktor yang dapat menyebabkan perubahan kondisi komunitas partisipasi masyarakat terhadap pelestarian hutan maka perlu di lakukan penelitian mengenai tingkat partisipasi masyarakat dalam pelestarian hutan cagar alam di kampong sapokren Waigeo barat yang terhubung langsung dengan Hutan Cagar Alam Waigeo Barat

Berdasarkan uraian latar belakang di atas, maka yang menjadi rumusan masalah dalam penelitian ini adalah:
1. Bagaimana partisipasi masyarakat terhadap pelestarian hutan cagar alam di Kampung Saporkren Distrik Waigeo Selatan Kabupaten Raja Ampat.

2. Bagaimana perilaku masyarakat terhadap upaya pelestarian hutan cagar alam di Kampung Saporkren Distrik Waigeo Selatan Kabupaten Raja Ampat.

Manfaat penelitian ini adalah :

1. Sebagai sumber informasi bagi pemerintah dalam membuat kebijakan terkait dengan pemanfaatan tumbuhan secara yang lestari dan berkelanjutan.

2. Sebagai sumber informasi para peneliti untuk melakukan penelitian selanjutnya.

\section{METODE PENELITIAN}

Metode yang di pakai dalam penelitian ini adalah metode deskriptif dengan teknik observasi dan wawancara. Penentuan sampel partisispasi masyarakat terhadap pelestarian hutan cagar alam dilakukan denga menggunakan metode purposive sampling (sampel bertujuan), di mana responden yang dipilih berdasarkan responden kunci yakni kepala suku, tokoh adat, tokoh agama, tokoh masyarakat, tokoh pemuda yang ada di lokasi penelitian.

Pengumpulan data dilakukan dengan cara pengisian daftar pertanyaan (kuisioner), melakukan wawancara guna mengetahui gambaran secara jelas terhadap keakuratan data yang dibutuhkan untuk menjawab rumusan masalah penelitian. 
Data yang digunakan dalam penelitian meliputi data primer yaitu yang diperoleh secara langsung dari responden kunci yang digunakan sebagi acuan dalam menjawab tujuan

\section{Prosedur Penelitian dan Teknik} Pengambilan data.

Prosedur penelitian yang akan digunakan dalam penelitian ini adalah:

1. Survei lapangan yang menentukan responden kunci yang dipilih berdasarkan status ketokohan dalam bermasyarakat yang ikut partisipasi pelestarian hutan Cagar Alam Waigeo Barat Kabupaten Raja Ampat.

2. Observasi secara langsung aktifitas dalam hal pelestarian cagar alam mengumpulkan data primer dan sekunder dapat menyiapkan quisioner berupa daftar pertanyaan guna untuk mengetahui gambaran secara jelas terhadap keakuratan data yang dibutuhkan untuk menjawab rumusan masalah terhadap penelitian ini.

3. Populasi dalam penelitian ini adalah seluruh masyarakat Distrik Waigeo Barat. Sedangkan responden sampel dipilih berdasarkan status social dalam komunitas adat dengan kategori : (1) Tokoh adat, (2) Tokoh agama, (3) Tokoh Masyarakat, (4) Masyarakat yang telah berkeluarga yang sering berinteraksi dengan

penelitian ini meliputi data primer dan data sekunder. Data primer diperoleh melaui pengamatan lapangan. Pengamatan lapangan dilakukan terhadap berbagai bentuk partisipasi masyarakat terhadap pelestarian hutan penelitian. Sedangkan data sekunder berupa informasi yang didapat dari kantor desa, perpustakaan serta instansi lainnya yang berhubungan dengan penelitian ini.

hutan dan memanfaatkan hasil hutan sebagai penyangga hidupnya.

Teknik penelitian yang akan digunakan dalam penelitian ini adalah:

1. Survei lapangan untuk mengetahui partisipasi masyarakat dalam memanfaatkan hutan Cagar Alam Distrik Waigeo Barat.

2. Observasi secara langsung terhadap aktivitas masyarakat yang berpartisipasi dan memanfaatkan hasil hutan cagar alam Distik Waigeo Barat.

3. Mewawancarai secara langsung kepada masyarakat yang berpartisipasi melestarikan terhadap hutan Cagar alam serta masyarakat yang memanfaatkan hasil hutan cagar alam sebagai usaha pokok keluarga.

4. Mengumpulkan data primer dan sekunder.

a. Data primer meliputi jenis hasil hutan.

b. Data sekunder meliputi keadaan umum lokasi penelitian dan social ekonomi masyarakat setempat.

5. Organisasi dan kompilasi data.

6. Analisis data.

Data yang diperoleh pada cagar alam di Distrik Waigeo Barat. Sedangkan wawancara dilakukan sesuai dengan isi kuisioner yang tersedia yang telah disiapkan menyangkut bentuk partisipasi masyarakan terhadap 
pelestarian hutan cagar alam di Distrik Waigeo Barat Kabupaten Raja Ampat

Data sekunder diperoleh melalui studi pustaka hasil-hasil penelitian sebelumnya, atau data dari kelurahan

\section{HASIL DAN PEMBAHASAN}

Distrik waigo selatan kabupaten raja ampat memiliki luas wilayah \pm 32 Ha dimana berbatasan langsung dengan kampung Saporkren

a. Partisisai Masyarakat Dalam Pelestarian Hutan Cagar Alam Di Kampung Sapokren

Partisipasi masyarakat dalam pelestarian hutan cagar alam penelitian ini terdiri atas kemauan, kemampuan dan kesempatan. Sesuai dengan kuisioner wawancara yang disebarkan dalam penelitian ini Diuraikan berikut ini :

1. Kemauan

Kemauan berpartisipasi dalam penelitian ini adalah kesediaan masyarakat untuk ikut serta dalam proses kegiatan perencanaan hutan cagar alam, apakah secara sukarela, terpaksa ataukah karena kebiasaan atau ikut-ikutan. dapat dilihat dalam tabel 1 . atau desa, instansi atau lembaga yakni terkait dengan penelitian manyangkut partisipasi masyarakat terhadap pelestarian hutan cagar alam serta keadaan umum lokasi penelitian.

Berdasarkan tabel 1. dapat diketahui bahwa mayoritas responden mempunyai motivasi secara sukarela untuk mengikuti partisipasi dalam pelestarian hutan cagar alam di Kampung Saporkren yaitu dengan mayoritas responden sebanyak 11 orang (55 persen). Dan ada 1 orang responden (5 persen) yang mengatakan bahwa mereka hanya ikut-ikutan. Meskipun demikian, keseluruhan dari responden yaitu sebanyak 20 orang (100 persen) mempunyai sikap menerima dengan sadar adanya kemauan Partisipasi masyarakat dalam pelestarian hutan cagar alam ini juga disadari masyarakat karna telah membuka lahan di pinggiran kawasan cagar alam. Sehingga berdasarkan tabel dibawah ini dapat diperoleh hasil tingkat kemauan berpartisipasi responden dalam ikut berpartisipasi dalam pelestarian hutan cagar alam. 


\section{Median Volume X Nomor 1 Bulan Februari 2018}

Tabel 1. Klasifikasi responden masyarakat untuk pelestarian hutan cagar alam di Kampung Saporkren berdasarkan persentase indicator

\begin{tabular}{|c|c|c|c|c|}
\hline Indicator & \multicolumn{2}{|c|}{ Kriteria } & $\begin{array}{l}\text { Jumlah } \\
\text { Responden } \\
\text { (KK) }\end{array}$ & $\begin{array}{l}\text { Persen } \\
(\%)\end{array}$ \\
\hline \multirow{3}{*}{$\begin{array}{c}\text { Motivasi } \\
\text { Mengikuti } \\
\text { kegiatan } \\
\text { Dan }\end{array}$} & 1. & Sukarela & 11 & 55 \\
\hline & 2. & Ikut-ikutan & 1 & 5 \\
\hline & 3. & Terpaksa & 0 & 0 \\
\hline \multirow{3}{*}{$\begin{array}{l}\text { Sikap terhadap } \\
\text { kegiatan }\end{array}$} & 4. & Menerima dengan sadar & 8 & 40 \\
\hline & 5. & Menerima dengan terpaksa & 0 & 0 \\
\hline & 6. & menolak & 0 & 0 \\
\hline Jumlah & & & 20 & 100 \\
\hline
\end{tabular}

Sumber : Analisis data primer, 2017

Secara keseluruhan tingkat kemauan responden dalam penyuluhan kegiatan perencanaan pelestarian hutan cagar

Tabel 2. Klasifikasi Partisipasi Kemauan responden ikut berpartisipasi dalam Pelestarian hutan cagar alam di Kampung Saporkren

\begin{tabular}{cccc}
\hline No & Klasifikasi & $\begin{array}{c}\text { Jumlah Responden } \\
(\mathrm{KK})\end{array}$ & Persen $(\%)$ \\
\hline 1. & Tinggi & 18 & 90 \\
2. & Sedang & 2 & 10 \\
3. & Rendah & 0 & 0 \\
\hline & Jumlah & $\mathbf{2 0}$ & $\mathbf{1 0 0}$ \\
\hline
\end{tabular}

Sumber : Analisis data primer, 2017

Berdasar tabel 8 dapat diketahui bahwa Partisipasi tingkat kemauan responden ikut ambil bagian dalam pelestarian hutan cagar alam di Kampung Saporkren berada dalam kategori tinggi yaitu sebanyak 90 persen dari 20 responden penelitian. Responden mempunyai pengetahuan yang cukup bahwa hutan cagar alam merupakan kawasan tersebut dilaksanakan dengan menjadi sistem zonasi dan dimanfaatkan bagi kepentingan penelitian dan pengembangan ilmu alam dapat dilihat dalam tabel berikut in: pengetahuan, pendidikan dan kegiatan lainnya yang menunjang kegiatan pelestarian hutan cagar alam. Motivasi responden secara sukarela dan menerima dengan sadar adanya partisipasi masyarakat dalam pelestarian hutan cagar alam menyebabkan tingkat kemauan responden untuk berpartisipasi termasuk dalam kategori tinggi. Responden menyadari bahwa Rencana pengelolaan cagar alam sekurangkurangnya memuat tujuan pengelolaan, dan garis besar kegiatan yang 


\section{\begin{tabular}{l|l} 
Median Volume X Nomor 1 Bulan Februari & 2018
\end{tabular}}

menunjang upaya perlindungan, pengawetan dan pemanfaatan kawasan. Upaya pengawetan kawasan cagar alam dilaksanakan dalam bentuk kegiatanta. a. perlindungan dan pengamanan kawasan; b. inventarisasi potensi kawasan dan c. penelitian dan pengembangan yang menunjang pengawetan.

2. Kemampuan

Kemampuan berpartisipasi dalam penelitian ini adalah masyarakat yang ikut serta dalam pelaksanaan kegiatan perencanaan pelestarian hutan cagar alam. Kemampuan berpartisipasi dapat dilihat dari kemampuan dalam memanfaatkan sumberdaya yang tersedia yaitu pada saat wisatawan berkunjung di kawasan hutan cagar alam masyarakat menawarkan suatu pengetahuan tentang hutan cagar alam akan kekayaan sumber daya hayati berupa flora dan fauna serta keindahan alam kepada mereka tentang hutan cagar alam Kampung Saporkren. Berdasarkan indicator-indikator kemampuan berpartisipasi dalam penelitian ini, didapat bahwa kemampuan berpartisipasi responden dalam menerima informasi hutan cagar alam di Kampung Saporkren dapat dilihat dalam tabel berikut ini :

Tabel 3. Kemampuan Partisipasi Responden dalam menerima informasi hutan cagar alam yang diberikan oleh pemerintah setempat

\begin{tabular}{clllcr}
\hline Indikator & & Tingkat Partisipasi & \multicolumn{2}{c}{$\begin{array}{c}\text { Jumlah } \\
\text { Responden }\end{array}$} & Persen (\%) \\
\cline { 4 - 5 } & & & Selalu & 14 & 70 \\
$\begin{array}{c}\text { Penyuluhan } \\
\text { informasi hutan } \\
\text { cagar alam }\end{array}$ & 2. & Sebagian & 4 & 20 \\
& 3. & tidak pernah & 2 & 10 \\
\hline & Jumlah & $\mathbf{2 0}$ & $\mathbf{1 0 0}$ \\
\hline
\end{tabular}

Sumber data : Data Primer 2017

Berdasar tabel 3 dapat diketahui bahwa sebagian besar responden (70\%) selalu mengambil bagian dalam penyuluhan informasi yang diberikan pemerintah setempat tentang pelestarian hutan cagar alam dan $20 \%$ cuma sebagian yang turut ambil bagian dikarenakan karena kurangnya kesempatan selain mereka ikut kegiatan pekerjaan rutin mere berkebun juga mereka harus prioritaskan.

3. Kesempatan
Kesempatan berpartisipasi dalam penelitian ini adalah masyarakat yang ikut serta dalam kegiatan partisipasi ini sebesar $40 \%$ dilihat pada tabel 3 dibawah ini. Kesempatan berpartisipasi dapat dilihat dari kesempatan responden untuk mendapatkan informasi-informasi tentang pelestarian hutan cagar alam dan keaktifan responden untuk ikut dalam mendengarkan penyuluhan yang ada. Berdasarkan indikator-indikator kesempatan berpartisipasi dalam 


\section{Median Volume X Nomor 1 Bulan Februari 2018}

penelitian ini, didapat bahwa

dalam mendengar penyuluhan dapat

kesempatan berpartisipasi responden

dilihat dalam tabel berikut ini :

dalam pelestarian hutan cagar alam

Tabel 4. Kesempatan Responden dalam partisipasi pelestarian hutan cagar alam di Kampung Saporkren

\begin{tabular}{|l|l|c|c|}
\hline \multirow{2}{*}{ Indikator } & \multicolumn{2}{|c|}{ Kriteria } & \multicolumn{2}{c|}{ Jumlah Responden } \\
\cline { 2 - 4 } & & $(\mathrm{KK})$ & Persen $(\%)$ \\
\hline \multirow{2}{*}{$\begin{array}{l}\text { Keaktifan dalam menjaga } \\
\text { kelestarian }\end{array}$} & Aktif & 9 & 45 \\
\cline { 2 - 4 } & Ikut tapi tidak aktif & 11 & 55 \\
\cline { 2 - 4 } & Tidak aktif & 0 & 0 \\
\hline & Jumlah & $\mathbf{2 0}$ & $\mathbf{1 0 0}$ \\
\hline
\end{tabular}

Sumber data: Data Primer, 2017

Berdasar tabel 4 dapat diketahui bahwa sebagian besar responden yaitu sebanyak 11 orang (55 persen) tidak mempunyai kesempatan keaktifan dalam melaksanakan kegiatan kesempatan menerima materi dalam penyuluhan tentang kelestarian hutan cagar alam.
Partisipasi masyarakat tentang Hutan cagar alam di kampung Saporkren Distrik Waigeo Selatan Kabupaten Raja Ampat disajikan pada tabel dibawah ini

Tabel 5.Distribusi Partisipasi msyarakat tentang Kegiatan pencegahan dan penanggulangan dari ancaman dan gangguan kerusakan hutan cagar alam di kampung Saporkren Distrik Waigeo Selatan Kabupaten Raja Ampat tahun 2017

\begin{tabular}{lllll}
\hline \multirow{2}{*}{ No } & \multicolumn{1}{c}{ Uraian } & \multicolumn{2}{c}{ Jumlah Masyarakat } & \multirow{2}{*}{$\sum$} \\
\cline { 3 - 4 } & & $\mathrm{A}$ & $\mathrm{B}$ & \\
\hline 1. & $\begin{array}{l}\text { Pertemuan dengan masyarakat pada saat } \\
\text { perencanaan pelestarian hutan cagar alam }\end{array}$ & 17 & 3 & 20 \\
2. & $\begin{array}{l}\text { Masyarakat sekitar ikut ambil bagian dalam } \\
\text { pelestarian hutan }\end{array}$ & 18 & 2 & 20 \\
3. & Menjaga stabilitas keamanan kawasan HCA & 16 & 4 & 20 \\
4. & $\begin{array}{l}\text { Pengetahuan tentang Hutan Cagar } \\
\text { 5. }\end{array}$ & 9 & 11 & 20 \\
\hline
\end{tabular}

Ket: $\mathrm{A}=\mathrm{Ya}, \mathrm{B}=$ Tidak merupakan variasi jawaban quisioner dari setiap responden Sumber : Data Primer Tahun 2017

Dari tabel diatas diketahui selain dari itu dari 20 responden bahwa tingginya peran pemerintah menyatakan bahwa 18 responden yang dalam pelestarian hutan cagar alam turut serta ambil bagian dalam untuk memberikan informasi kepada masyarakat yang minim pendidikan dan pelestarian hutan cagar alam yang mereka telah menganggap bahwa hutan 


\section{Median Volume X Nomor 1 Bulan Februari 2018}

tersebut adalah warisan leluhur dan patut untuk selalu dijaga dan dilestarikan cukup tinggi dari hasil pengambilan sampel penelitian. Dari 20 responden namun ada 11 reponden yang sama sekali tidak mengetahui bahwa hutan disekitar kampung Saporkren adalah hutan cagar alam yang patut dan wajib untuk dilindungi namun walaupun mereka kurang mengetahui tentang arti dari perlindungan hutan, bahwa masyarakat sendiri punya inisiatif untuk selalu melindungi warisan leluhur mereka yaitu hutan.

\section{b. Persepsi Masyarakat Kampung} Saporkren Tentang Hutan Cagar Alam Distrik Waigeo Selatan

Persepsi masyarakat menurut Rakhmat (2003) dipengaruhi oleh faktor-faktor eksternal (kebaruan, perulangan) dan internal (minat, kondisi biologis, dan kebiasaan) Persepsi masyarakat Kampung Saporkren mengenai hutan cagar alam dan kebijakan pengelolaan hutan cagar alam dipengaruhi oleh beberapa faktor, diantaranya 1) Pendidikan masyarakat yang relatif rendah yaitu sebagian besar hanya mengenyam Sekolah Dasar /SD dan Sekolah Menengah Pertama/SMP sebesar $45 \%$. Hal ini mempengaruhi proses penerimaan masyarakat terhadap informasi sehingga wawasan pengetahuan mereka terbatas serta mempengaruhi proses penyuluhan dan pembinaan dari Penyuluh Kehutanan setempat dalam memahami materi yang diberikan.

Dari hasil wawancara dengan penyuluh Kehutanan mengenai data responden, masyarakat tidak dapat memahami secara langsung materi, dan penyuluh harus mengulangi sampai beberapa kali. Pengetahuan yang diperoleh secara turun temurun, khususnya berkaitan dengan pelestarian hutan hutan cagar alam. Masyarakat memandang bahwa hutan perlu dijaga dan dilestarikan agar tidak terjadi bencana longsor dan kekeringan. Sebagian besar masyarakat bermata pencaharian sebagai petani sehingga ketergantungan terhadap lahan dan ketersediaan air sangat tinggi. Hutan diperlukan agar air tetap ada meskipun pada musim kemarau dan mereka dapat terus mengolah lahannya sehingga dapat berproduksi.

Persepsi masyarakat tentang Hutan cagar alam di kampung Saporkren Distrik Waigeo Selatan Kabupaten Raja Ampat disajikan pada tabel 6. dan penjelasan sebagai berikut : 


\section{Median Volume X Nomor 1 Bulan Februari 2018}

Tabel 6. Persepsi masyarakat tentang Kegiatan pencegahan dan penanggulangan dari ancaman dan gangguan kerusakan hutan cagar alam di kampung Saporkren Distrik Waigeo Selatan Kabupaten Raja Ampat tahun 2017

\begin{tabular}{llccc}
\hline \multirow{2}{*}{ No. } & \multicolumn{1}{c}{ Uraian } & \multicolumn{2}{c}{ Jumlah Masyarakat } & \multirow{2}{*}{$\sum$} \\
\cline { 3 - 4 } & & $\mathrm{A}$ & $\mathrm{B}$ & \\
\hline 1. & Pemasangan Plang Tanda larangan & 14 & 6 & 20 \\
2. & Kegiatan Penyuluhan secara rutin & 13 & 7 & 20 \\
3. & Pengadaan Petugas Keamanan HCA & 2 & 18 & 20 \\
4. & Pengetahuan tentang Hutan Cagar Alam & 10 & 10 & 20 \\
5. & Partisipasi masyarakat & 18 & 2 & 20 \\
\hline
\end{tabular}

Ket: $\mathrm{A}=\mathrm{Ya}, \mathrm{B}=$ Tidak merupakan variasi jawaban quisioner dari setiap responden Sumber : Data Primer Tahun 2017

Berdasarkan Tabel diatas dapat lihat bahwa hampir sebagian besar masyarakat mengetahui adanya pemasangan plang tanda larangan pada kawasan hutan cagar alam berguna untuk mencegahan hutan dari kerusakan hal ini terlihat jumlah masyarakat sebesar 14 responden menyatakan Ya dan reponden terendah adalah di pengadaan petugas dalam keamanan dan menjaga kawasan hutan berguna untuk melindungi hutan cagar lama dari perambahan hutan yang sangat minim sebanyak nol responden yang mengetahui adanya petugas keamanan yang masyarakat tau bahwa merekalah yang menjaga keamanan pada wilayah yang berada di areal hutan sekitar Kampung Saporkren.

Berdasarkan pengamatan dan wawancara di lapangan diketahui bahwa sebagian masyarakat yaitu sebanyak 18 responden ikut berpartisipasi sekitar kawasan dalam kegiatan pencegahan dan penanggulangan hutan cagar alam dari ancaman atau gangguan kerusakan hutan cagar Dari tabel diatas dapat dilihat bahwa jumlah masyarakat yaitu sebanyak 10 responden mengetahui informasi tentang hutan cagar alam yang patut untuk dilindungi.

Diketahui bahwa semua responden masyarakat Kampung Saporkren yaitu sebanyak 20 Responden mendapatkan pengetahuan penyuluhan tentang Kegiatan pencegahan dan penanggulangan dari ancaman dan gangguan kerusakan hutan cagar alam di kampung Saporkren Distrik Waigeo Selatan Kabupaten Raja Ampat

c. Perilaku Masyarakat Tentang Upaya Pelestarian Hutan Cagar Alam Di Kampung Saporkren Distrik Waigeo Selatan

Keberlanjutan kelestarian hutan cagar alam dapat dilihat pada upaya pelestariannya dan kesadaran masyarakat akan pentingnya keberadaan hutan tersebut. Dari hasil wawancara bahwa Masyarakat mengaku sudah merasakan fungsi keberadaan hutan cagar alam terutama untuk menahan longsor, mengurangi bencana banjir, konservasi tanah, iklim yang baik serta ketersediaan air.

Upaya pelestarian ini didukung dengan sering adanya penyuluhan 


\section{\begin{tabular}{l|l} 
Median Volume X Nomor 1 Bulan Februari & 2018
\end{tabular}}

informasi dari pemerintah kerkait tentang kelestarian hutan cagar alam dan lingkungan. Perilaku Masyarakat terkait Aspek dalam pelestarian hutan cagar alam dapat lihat dari antar anggota interaksi masyarakat maupun dengan pihak terkait. Dari interaksi sosial yang terjalin kerjasama dengan stake holder dalam mengelola dan memajukan hutan cagar alam di kampung Saporkren, Perilaku masyarakat ini dapat dilihat pada partisipasi masyarakat dalam kegiatan hutan cagar alam, kerjasama dengan pihak terkait tingginya peran pemerintah dalam pelestarian hutan cagar alam untuk memberikan informasi kepada masyarakat yang minim pendidikan dan selain dari itu dari 20 responden menyatakan bahwa 18 responden yang turut serta ambil bagian dalam pelestarian hutan cagar alam yang mereka telah menganggap bahwa hutan tersebut adalah warisan leluhur dan patut untuk selalu dijaga dan dilestarikan cukup tinggi.

Norma yang dianut masyarakat berkaitan dengan pelestarian Hutan dan lingkungan termasuk di dalamnya hutan cagar alam yaitu pelarangan mengambil material dan satwa dari kawasan hutan. Pelarangan ini dimaksudkan untuk melindungi keberadaan satwa khususnya burung yang ada di kawasan hutan cagar alam.

Norma- norma di atas disahkan melalui Peraturan kampung dalam hal ini wawancara langsung dengan kepala kampung Bapak Orgenes kabir (Wawancara Tanggal 10 - September - 2017 Jam 12.45 WIT) tentang Pelestarian Hutan Cagar Alam. yang mengatakan : 'Setiap warga

masyarakat dilarang menangkap berbagai jenis burung dengan cara apapun di kawasan hutan dan lingkungan kampung' serta'. 'Larangan Mengambil batu/pasir/ material lain pada lingkungan kawasan hutan cagar alam. Norma tersebut bertujuan agar fungsi hutan sebagai tempat/ habitat hidup tanaman dan satwa serta mencegah tanah longsor dapat terjaga.

Perilaku Masyarakat berkaitan dengan Aspek Budaya Kearifan lokal merupakan nilai-nilai yang dimiliki masyarakat dalam berinteraksi di lingkungannya. Menurut Keraf (2002) kearifan lokal adalah semua bentuk pengetahuan, keyakinan, pemahaman atau wawasan serta adat kebiasaan atau etika yang menuntun perilaku manusia dalam kehidupan di dalam komunitas ekologis. Bentuk kearifan lokal yaitu pelarangan terhadap penebangan pohon pada areal pemakaman atau di dekat mata air.

\section{Kesimpulan}

Partisipasi masyarakat dalam pelestarian hutan cagar alam penelitian ini terdiri atas kemauan, kemampuan dan kesempatan. Partisipasi dalam hal antara lain : kemauan responden untuk ikut ambil bagian dalam pelestarian hutan cagar alam di Kampung Saporkren berada dalam kategori tinggi yaitu sebanyak 90 persen, kemampuan responden untuk ikut ambil bagian dalam penyuluhan pelestarian hutan cagar alam sebesar responden (70\%) selalu mengambil bagian dalam penyuluhan informasi yang diberikan 


\section{Median Volume X Nomor 1 Bulan Februari 2018}

pemerintah setempat tentang pelestarian hutan cagar alam dan kesempatan berpartisipasi dalam penelitian ini merupakan peluang yang dimiliki masyarakat untuk ikut serta dalam kegiatan partisipasi ini sebesar $70 \%$.

Perilaku masyarakat tentang upaya pelestarian dapat dilihat dari motivasi responden mengikuti kegiatan penyuluhan yang dilakukan oleh pemerintah setempat yang mencapai $55 \%$ dalam tingkat sukarela motivasi masyarakat yang ikut ambil bagian dalam menjaga dan melestarikan hutan cagar alam di Kampung Saporkren Distrik Waigeo Selatan.

\section{DAFTAR PUSTAKA}

Arafah , N., Darusman, D., Suhardjito, D., Sundawati, J., 2008. Kaindea: Adaptasi Pengelolaan Hutan Masyarakat di Pulau-Pulau Kecil. Jurnal Manajemen Hutan Tropika Vol. XIV (3).
Djadmiko. 2007. Evaluasi Pengelolaan Kawasan Cagar Alam Mandor di Kabupaten Landak Provinsi Kalimantan Barat. Tesis Program Magister Ilmu Lingkungan. Program Pascasarjana Universitas Diponegoro: Semarang.

Hardjosoemantri, Koesnadi. 1993. Hukum Perlindungan Lingkungan Konservasi Sumber Daya Alam Hayati dan Ekosistemnya. Gadjah Mada University Press. Yogyakarta.

Haeruman, Herman. 1988. Masalah Sosial dalam Pembangunan Kehutanan. Makalah pada Seminar Pascasarjana UI, 4-5 November 1992. Jakarta.

Papua Barat dalam angka 2015. Badan Pusat Statistik Provinsi Papua Barat. BPS

Sonny Keraf. 2002. Etika lingkungan Kawasan Hutan Konservasi (Jakarta Penerbit Kompas) Hal 103.122

Soetrisno, Lelenoh. 1994. Menuju Masyarakat Partisipasi. Kanisius. Jakarta 